\title{
A Structured Literature Review about the Role of Management Accountants in Sustainability Accounting and Reporting
}

\author{
Ilenia Ascani *, Roberta Ciccola and Maria Serena Chiucchi
}

Citation: Ascani, I.; Ciccola, R.;

Chiucchi, M.S. A Structured

Literature Review about the Role of

Management Accountants in

Sustainability Accounting and

Reporting. Sustainability 2021, 13,

2357. https://doi.org/10.3390/

su13042357

Academic Editor: Paola Demartini

Received: 10 January 2021

Accepted: 13 February 2021

Published: 22 February 2021

Publisher's Note: MDPI stays neutral with regard to jurisdictional claims in published maps and institutional affiliations.

Copyright: (c) 2021 by the authors. Licensee MDPI, Basel, Switzerland. This article is an open access article distributed under the terms and conditions of the Creative Commons Attribution (CC BY) license (https:/ / creativecommons.org/licenses/by/ $4.0 /$ )

Department of Management, School of Economics “G. Fuà", Università Politecnica delle Marche, Piazzale Martelli, 8, 60121 Ancona, Italy; r.ciccola@univpm.it (R.C.); m.s.chiucchi@univpm.it (M.S.C.)

* Correspondence: i.ascani@univpm.it

\begin{abstract}
Management accountants have proven to be pivotal for introducing new forms of accounting and reporting in companies to support managers in their decision-making process. The purpose of this paper is to review the literature on the role management accountants play in sustainability accounting and reporting to understand how research is progressing, point out its focus, critique its developments, and finally, identify future research avenues. Results reveal that, to date, management accountants' level of involvement is lower than that of non-accountants and that there is a consensus in academia and practice that a more significant involvement of management accountants is needed for promoting homogenization of sustainability accounting and reporting in companies and its more widespread diffusion and use among managers, thus embedding sustainability in corporate strategy and practices. Our findings show that more active involvement of management accountants depends, among other things, on their ability to broaden their competencies to include other domains of expertise and on the role of accounting education in improving their sustainability knowledge. Therefore, we call for more research on the competencies, skills, and roles that management accountants should play in order to promote the adoption and improvement of sustainability accounting and reporting.
\end{abstract}

Keywords: sustainability accounting; sustainability reporting; management accountants; controllers; management accounting; managerial reporting; structured literature review

\section{Introduction}

Over the last three decades, pressures from external stakeholders and new normative requirements for regulatory compliance as well as managers initiatives provided by managers have increased the relevance of sustainability accounting and reporting in numerous companies and in society, in general.

In order to ensure that sustainability practices become deeply rooted in organizations and embedded in corporate strategy, it is necessary that management accounting and reporting integrate sustainability measures and tools that help managers include sustainability criteria in their decision-making processes and in organizational daily routines [1-7].

Literature has amply shown that a key actor for the effective design and implementation of management accounting and reporting is the management accountant. This figure has also proven to be pivotal for pushing the actual use of information by managers, thus influencing their decision-making process [8-10], and for driving innovations in management accounting and reporting [11-13]. In particular, research has demonstrated how the management accountant is essential for introducing new forms of internal business reporting in companies, such as the Intellectual Capital Report, and in fostering their use within organizations [8,14-16]. In this regard, Chiucchi [8] has shown how the management accountant has been fundamental in managers' focus on Intellectual Capital (IC) and, by influencing their learning process, the management accountant has promoted IC reporting practices and the inclusion of variables related to IC in their decision-making processes. The relevance of the accounting function in adopting new forms of internal business reporting has also been underscored by Mio et al. [17] who illustrate and discuss 
the introduction of an Internal Integrated Report in a company, inspired by the Integrated Report proposed by the International Integrated Reporting Council (IIRC), to support managerial decision-making processes.

Considering the importance that literature generally attributes to management accountants not only in introducing accounting innovations that support managerial decisionmaking processes, but also in implementing new forms of internal business reporting, it would be interesting to explore the role that management accountants may have in companies to adopt and implement sustainability accounting and reporting. This theme has garnered interest also in practice: Professional management accounting associations, such as the Chartered Institute of Management Accountants (CIMA), call for management accountants' involvement in sustainability, because they have the competencies to measure and report information and thus, can play a key role in promoting sustainability accounting and reporting [18].

Against this background, the purpose of this paper is to review and critique, through a Structured Literature Review (SLR) [19], the current state of the art of the literature on management accountants' role in sustainability accounting and reporting and ultimately, to delineate emerging trends and identify avenues for future research.

Our study contributes to this contemporary field of research by showing that, to date, the involvement of management accountants in sustainability accounting and reporting appears to be marginal compared to that of non-accountants, such as sustainability managers, engineers, or other functional managers. As is seen in literature, there is a wide consensus on the need to involve management accountants in sustainability accounting and reporting to a greater degree in the future. In keeping with this line, the results of our SLR also seem to indicate that this future, potentially pivotal involvement of management accountants will depend on their ability to broaden their existing domain of expertise by acquiring new skills and competencies related to sustainability. After critically analyzing the status quo of existing research on the relationship between the management accountant's role and sustainability accounting and reporting, the present paper identifies future areas of research related to management accountants' involvement and role, to the harmonization and standardization of sustainability information and their implications for management accountants, and, finally, to the relevance of education in sustainability accounting and reporting for future management accountants. Lastly, reflections on how investigating these research areas may also have practical implications are provided.

The remainder of the paper is structured as follows. Section 2 illustrates and justifies the use of the Structured Literature Review method; Sections 3 and 4 present the results of the SLR, providing insights on and a critique of the literature analyzed. Lastly, Section 5 discusses the findings, offers indications for future research opportunities, and provides conclusions.

\section{Research Method}

In order to understand how the academic literature exploring management accountants' role in sustainability accounting and reporting has developed over the years, as well as what topics have been studied and what the future research avenues could be, we conducted a structured literature review. From a methodological perspective, several methods have been proposed to carry out a literature review, such as the traditional authorship review, the narrative review, the systematic review, and the structured literature review. These review methods differ from each other according to the rigidity of the rules to be followed. Systematic and structured reviews adopt a replicable and transparent process to minimize bias and subjectivity that may characterize traditional literature reviews [19-22]. In fact, the latter has been criticized since "the determination of which studies are to be included in the review and the appraisal of study quality can be subjective. Such reviews are often partial and rarely include all studies relating to a particular issue" [20] (p. 216). Therefore, to overcome these problems, more reproducible review methods such as the systematic and structured literature reviews have been developed and applied. The sys- 
tematic literature review is a "replicable, scientific and transparent process, in other words a detailed technology, that aims to minimize bias through exhaustive literature searches of published and unpublished studies and by providing an audit trail of the reviewers decisions, procedures and conclusions" [22] (p. 209). In contrast to traditional reviews, the systematic literature review requires the writing of a review protocol and the provision of a detailed description of the search process; first applied in the medical sciences, it was later adopted in the management and accounting literature [19,22]. In 2016, Massaro et al. [19] proposed the Structured Literature Review (SLR), a "method for studying a corpus of scholarly literature, to develop insights, critical reflections, future research paths and research questions" [19] (p. 2). Similar to the systematic literature review, the SLR follows a set of rigid rules in its development, but it is strictly characterized by "an explicit method following specific steps" [19] (p. 770). The SLR method necessarily involves ten fundamental steps which cannot be sidestepped, meaning that researchers must focus on certain aspects which aim to test the reliability and the validity of the literature review [19]. This process is designed to help researchers avoid certain risks, such as missing seminal articles, and contributes to reducing researchers' bias and subjectivity [19], leading to a reliable analysis of the literature as "it helps to yield different outcomes that are defensible" [19] (p. 769). For these reasons, we decided to adopt the Structured Literature Review (SLR) method and to apply the 10 steps identified by Massaro et al. [19]:

1. Write a literature review protocol;

2. Define the questions that the literature review is setting out to answer;

3. Determine the type of studies to include and carry out a comprehensive literature search;

4. Measure article impact;

5. Define an analytical framework;

6. Establish literature review reliability;

7. Test literature review validity;

8. Code data using the developed framework;

9. Develop insights and critique through dataset analysis;

10. Develop future research paths and questions.

The following sections illustrate the application of the SLR method to our research topic by highlighting the most relevant choices and elements that characterize each step of the literature review carried out.

\section{The Structured Literature Review}

\subsection{The Literature Review Protocol}

In this step, we describe the motivations for this research project and how we decided to approach this stream of literature. As far as the motivation is concerned, we were aware that sustainability accounting and reporting is a contemporary research field that has garnered growing attention from accounting researchers as well as practitioners in recent years. In this regard, it appears interesting to explore management accountants' role in sustainability, given that the extant literature has shown how they can play a pivotal role in introducing innovations in management accounting and reporting. Therefore, we decided to carry out a literature review, a Structured Literature Review (SLR), specifically, to understand the state of research on the role played by management accountants in sustainability accounting and reporting and to offer insights on future developments.

In our initial meetings, we designed the research plan to be carried out. In particular, we chose the Scopus database as our source of information and we identified the combination of search fields, such as keywords, date of publication, and document type. Then, we identified inclusion and exclusion criteria for selecting publications to include in our dataset. A detailed description of the literature search is provided in Section 3.3. Lastly, we determined the units of analysis to analyze the publications included in the final dataset, as described in Section 3.5. 


\subsection{The Research Questions}

The motivation for this research project, highlighted in the literature review protocol, and the research gap that it endeavors to fill, led us to formulate the research questions that would guide our research and that represent the second step of the SLR. According to Massaro et al. [19] (p. 744), an SLR "needs to critique an existing field of knowledge before it can offer a path towards future research". Drawing upon Alvesson and Deetz [23] and the three tasks of critical research that they identified, i.e., "insight", "critique", and "transformative redefinitions", Massaro et al. [19] state that at least three research questions should guide an SLR. The first research question should provide answers to how a stream of literature has progressed over time; this can be done by analyzing, for example, publications' impact, trend, and distribution among journals, books, etc. The second research question should offer a critical analysis of the developments of a certain research field, and, in this aim, an analytical framework must be developed to shed light on the foci that characterize the literature examined. In particular, the analytical framework should be composed of different units of analysis to organize and examine existing studies and their main findings and it should foster a critique of the literature in question. This will pave the way to answering the third research question, which is aimed at identifying new directions for future research that could contribute to expanding knowledge on the issue at stake.

Therefore, by adapting the three research questions identified by Massaro et al. [19] to the specific topic under investigation in this article, we formulate the following research questions:

RQ.1 How is research for inquiring into the role of management accountants in sustainability accounting and reporting developing?

RQ.2 What is the focus and critique of the research on the role of management accountants in sustainability accounting and reporting?

RQ.3 What future avenues of research on the role of management accountants in sustainability accounting and reporting can be identified?

\subsection{Type of Studies and Literature Search}

The third step consists in selecting what type of studies is relevant to the research and carrying out the literature search. First, databases are selected and keywords are determined in order to identify papers suitable for this study. We chose Scopus as the database for publication selection since it is "one of the most appropriate data warehouses for literature review studies" [24] (p. 3229), thanks to its broad coverage of academic peer-reviewed literature [24,25]. Then, we identified the relevant keywords for our research and we used them to construct the search string that was applied to "titles, abstracts, and keywords" for publications published in English and included in the "Business, Management and Accounting" area. The search string consisted of two parts; the first concerned sustainability accounting and reporting and the second related to management accountants. It included the following keywords: "sustainability" OR "sustainable practice" OR "sustainability practice*" OR "sustainable development" OR "SDG*" OR "sustainable report" OR "sustainability report*" OR "sustainability reporting" OR "sustainability accounting" AND "controller*" OR "accountant*" OR "management accountant" OR "CFO" OR "Chief Financial Officer*".

The part of the search string devoted to sustainability accounting and reporting includes various terms that refer to the sustainability accounting and reporting domain, like "sustainability accounting", "sustainability report", and "sustainability reporting", which, to date, represent one of the most common accounting tools used to account for sustainability [26]. It also includes terms that are strictly related to sustainability, such as "sustainable development", "sustainability practices", and "Sustainable Development Goals (SDGs)". The part concerning the management accountant, in turn, includes the words "management accountants" and "controllers" because in some countries, e.g., German-speaking countries, "controller" is used as a synonym for management accountant [27]. This part of the string also includes the words "Chief Financial Officer" and "CFO" because they may also act as 
management accountants, in some companies. Finally, we included the term "accountant" because, in the accounting literature, it is sometimes used as a synonym for "management accountant". It is important to specify here that, in the search string we included different terms to find papers on the role of management accountants in sustainability accounting and reporting, such as "CFO" or "accountant". Nevertheless, we selected and included in our SLR only those publications that specifically focus on management accountants, i.e., that are specifically referred to management accounting and controlling. This was made possible through the reading of the abstracts and the full texts which provide information to clearly understand the focus of the papers. Therefore, in the remainder of the article, we only use the term "management accountants" to refer to those professionals who are in charge of management accounting.

In order to accomplish an exhaustive search and to collect the most relevant studies on the topic, we did not exclude any journals. For the same reason, we did not limit the search to journal articles, but also included books, book chapters, and working papers; nor did we define a specific time frame. The search process, carried out on 12 October 2020, yielded 202 studies and the basic information like author(s), title, year of publication, abstract, etc., was retrieved.

In determining which studies should be included or excluded, we defined inclusion and exclusion criteria. We included publications whose main topic was the role and involvement of management accountants in sustainability accounting and reporting. Likewise, we excluded articles where the management accountant was just one of the recipients of specific recommendations rather than the main topic of the study; we also excluded studies where the term "accountant" referred to auditors or fiscal experts as well as publications where the term "controller" referred to electromechanical devices.

The decision to exclude or include any publication was based, first, on reading the title, keywords, and abstract; then, if the information included in the abstract was not sufficient to include or exclude a study, the full text was read. At the end of this process, we had identified 46 publications, which we began to read in full. As we analyzed them, we realized that some publications, while explicitly referring to the role of management accountants in sustainability accounting and reporting in their abstracts, in the full text management accountants might simply be mentioned in passing or, along with other accounting professionals, were merely the recipients of general comments on sustainability accounting and reporting. We excluded these publications, thus obtaining a final sample of 23 studies published between 2001 and 2020 (see Appendix A).

\subsection{Publication Impact}

The fourth step of the SLR entails measuring the articles' impact. A proxy of an article's quality and impact can be the measurement of citations; in this paper, the focus is on citations and citations per year (CPY) based on Google Scholar metrics. The publications citation information was downloaded from the software Harzing's Publish or Perish 7 on November 30, 2020. We use this tool as it displays the most stable and comprehensive coverage [28,29] and it has been applied also in previous SLRs e.g., [25,30,31]. While "citations" refers to the total citations received by a study to date, "citations per year" is the total number of citations divided by the number of the years between the publication year and the current year. In this regard, the CPY counterbalances the fact that older studies can collect more citations than the most recent ones. Tables 1 and 2 show the top five publications by citations and CPY [32-36]; it is possible to observe that the first three of the top five publications are ranked in the same order in both tables, while Fraser [35] and Çalişkan [36] switch their respective positions. It is worth underlining that four out of five studies are published in academic journals, while Tilt [34] is a book chapter. Management accounting is one of the main areas of interest in three out of the four journals, while the other one (i.e., Social Responsibility Journal) focuses primarily on social responsibility. 
Table 1. Top five articles by citations.

\begin{tabular}{|c|c|c|c|c|}
\hline & Reference & Article & Journal/Book & $\begin{array}{l}\text { Google Scholar } \\
\text { Citations }\end{array}$ \\
\hline 1 & Jones [32] & $\begin{array}{l}\text { Accounting for the environment: Towards a } \\
\text { theoretical perspective for environmental } \\
\text { accounting and reporting }\end{array}$ & Accounting Forum & 303 \\
\hline 2 & $\begin{array}{c}\text { Ballou, Casey, Grenier } \\
\text { and Heitger [33] }\end{array}$ & $\begin{array}{l}\text { Exploring the strategic integration of } \\
\text { sustainability initiatives: Opportunities for } \\
\text { accounting research }\end{array}$ & Accounting Horizons & 179 \\
\hline 3 & Tilt [34] & $\begin{array}{c}\text { Corporate responsibility, accounting } \\
\text { and accountants }\end{array}$ & $\begin{array}{l}\text { Professionals Perspectives of } \\
\text { Corporate Social Responsibility }\end{array}$ & 116 \\
\hline 4 & Fraser [35] & $\begin{array}{c}\text { "Fleshing out" an engagement with a social } \\
\text { accounting technology }\end{array}$ & $\begin{array}{l}\text { Accounting, Auditing and } \\
\text { Accountability Journal }\end{array}$ & 68 \\
\hline 5 & Çalişkan [36] & $\begin{array}{l}\text { How accounting and accountants may } \\
\text { contribute in sustainability? }\end{array}$ & Social Responsibility Journal & 58 \\
\hline
\end{tabular}

Table 2. Top five articles by Citations Per Year (CPY).

\begin{tabular}{|c|c|c|c|c|}
\hline & Reference & Article & Journal/Book & $\begin{array}{c}\text { Google Scholar } \\
\text { CPY }\end{array}$ \\
\hline 1 & Jones [32] & $\begin{array}{l}\text { Accounting for the environment: Towards a } \\
\text { theoretical perspective for environmental } \\
\text { accounting and reporting }\end{array}$ & Accounting Forum & 30.3 \\
\hline 2 & $\begin{array}{c}\text { Ballou, Casey, Grenier } \\
\text { and Heitger [33] }\end{array}$ & $\begin{array}{c}\text { Exploring the strategic integration of } \\
\text { sustainability initiatives: Opportunities for } \\
\text { accounting research }\end{array}$ & Accounting Horizons & 22.28 \\
\hline 3 & Tilt [34] & $\begin{array}{c}\text { Corporate responsibility, accounting } \\
\text { and accountants }\end{array}$ & $\begin{array}{l}\text { Professionals Perspectives of } \\
\text { Corporate Social Responsibility }\end{array}$ & 10.55 \\
\hline 4 & Çalişkan [36] & $\begin{array}{l}\text { How accounting and accountants may } \\
\text { contribute in sustainability? }\end{array}$ & Social Responsibility Journal & 9.67 \\
\hline 5 & Fraser [35] & $\begin{array}{l}\text { "Fleshing out" an engagement with a social } \\
\text { accounting technology }\end{array}$ & $\begin{array}{l}\text { Accounting, Auditing and } \\
\text { Accountability Journal }\end{array}$ & 8.5 \\
\hline
\end{tabular}

\subsection{The Analytical Framework}

The coding framework is partly based on similar units of analysis adopted in previous SLRs and partly developed ad hoc in this paper to enrich our understanding of the role of management accountants in sustainability accounting and reporting. As a result, 10 categories, which we can also call "units of analysis", were developed for coding the articles. Table 3 summarizes these categories and their attributes.

The first category classifies publications according to the author type (A). In line with Dumay et al. [30], this category helps to pinpoint whether the topic under investigation has been of interest to academics and/or practitioners/consultants.

The second category, "Location" (B), refers to the country of research and was adopted by Guthrie et al. [37], Dumay et al. [30], and Massaro et al. [25]. Differently from these previous studies, we decided to use the five continents as general attributes, without further classifying our selected studies by specific regions or countries. This was done because we did not expect to see a significant number of papers from specific countries, as did happen, for example, for Dumay et al. [30] in their SLR on Integrated Reporting. However, during the coding process, we took note of the specific countries where studies took place and, where relevant, we have commented on this aspect in Section 4.2. By adopting this unit of analysis, we can identify where, i.e., on which continents, the literature on the role of management accountants in sustainability accounting and reporting has been mostly developed. 
Table 3. Analytical framework, Krippendorff's alpha, and summary of results.

\begin{tabular}{|c|c|c|c|c|c|c|c|}
\hline & & & K-alpha & & & & K-alpha \\
\hline A & Author Type & & 1.000 & B & Location & & 1.000 \\
\hline A1 & Academic(s) & 22 & & B1 & Africa & 1 & \\
\hline $\mathrm{A} 2$ & Practitioner(s) and consultant(s) & 1 & & B2 & The Americas & 1 & \\
\hline \multirow[t]{6}{*}{ A3 } & Academic(s), practitioner(s) and consultant(s) & 0 & & B3 & Asia & 1 & \\
\hline & Total & 23 & & B4 & Europe & 5 & \\
\hline & & & & B5 & Oceania & 8 & \\
\hline & & & & B6 & Other & 7 & \\
\hline & & & & & Total & 23 & \\
\hline & & & K-alpha & & & & K-alpha \\
\hline $\mathrm{C}$ & Jurisdiction & & 1.000 & $\mathbf{D}$ & Organizational focus & & 1.000 \\
\hline $\mathrm{C} 1$ & Supra-national/International/Comparative-General & 7 & & D1 & Publicly listed companies & 0 & \\
\hline C1.1 & Supra-national/International/Comparative-Industry & 0 & & D2 & Private companies & 3 & \\
\hline C1.2 & Supra-national/International/Comparative-Organizational & 2 & & D3 & Public sector & 5 & \\
\hline $\mathrm{C} 2$ & National-General & 2 & & D4 & Not for profit & 0 & \\
\hline $\mathrm{C} 2.1$ & National-Industry & 5 & & D5 & General/Other & 15 & \\
\hline $\mathrm{C} 2.2$ & National-Organizational & 4 & & & Total & 23 & \\
\hline \multirow[t]{3}{*}{$\mathrm{C} 3$} & One organization & 3 & & & & & \\
\hline & Total & 23 & & & & & \\
\hline & & & K-alpha & & & & K-alpha \\
\hline E & Research method & & 1.000 & $\mathbf{F}$ & Sustainability definition & & 0.928 \\
\hline E1 & Case/field study/interviews & 5 & & $\mathrm{~F} 1$ & Environmental-Social-Economic & 12 & \\
\hline E2 & Content analysis/historical analysis & 0 & & F2 & Environmental-Social & 4 & \\
\hline E3 & Survey/Questionnaire/Other empirical & 5 & & F3 & Environmental-Economic & 0 & \\
\hline E4 & Mixed methods & 4 & & F4 & Social-Economic & 0 & \\
\hline E5 & Commentary/Normative/Policy & 8 & & F5 & Environmental & 7 & \\
\hline \multirow[t]{4}{*}{ E6 } & Literature review & 1 & & F6 & Social & 0 & \\
\hline & Total & 23 & & F7 & Economic & 0 & \\
\hline & & & & & Total & 23 & \\
\hline & & & K-alpha & & & & K-alpha \\
\hline G & Sustainability accounting and reporting focus & & 0.861 & $\mathbf{H}$ & $\begin{array}{l}\text { Management accountant's } \\
\text { current involvement in } \\
\text { sustainability accounting and } \\
\text { reporting }\end{array}$ & & 0.940 \\
\hline G1 & Internal: measurement and management & 5 & & $\mathrm{H} 1$ & $\begin{array}{l}\text { No involvement in sustainability } \\
\text { accounting and reporting }\end{array}$ & 1 & \\
\hline G2 & External: disclosure & 5 & & $\mathrm{H} 2$ & $\begin{array}{l}\text { Low involvement in sustainability } \\
\text { accounting and reporting }\end{array}$ & 9 & \\
\hline \multirow[t]{4}{*}{ G3 } & $\begin{array}{l}\text { Internal and external: measurement, management, } \\
\text { and disclosure }\end{array}$ & 13 & & $\mathrm{H} 3$ & $\begin{array}{l}\text { Involvement in sustainability } \\
\text { accounting and reporting }\end{array}$ & 3 & \\
\hline & 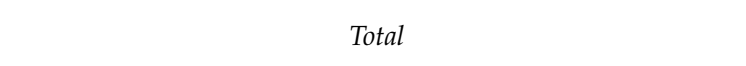 & 23 & & $\mathrm{H} 4$ & $\begin{array}{l}\text { High involvement in sustainability } \\
\text { accounting and reporting }\end{array}$ & 2 & \\
\hline & & & & H5 & $\begin{array}{c}\text { Not specified } \\
\text { Total }\end{array}$ & $\begin{array}{c}8 \\
23\end{array}$ & \\
\hline & & & K-alpha & & & & K-alpha \\
\hline I & $\begin{array}{l}\text { Management accountant's future/potential involvement } \\
\text { in sustainability accounting and reporting }\end{array}$ & & 0.839 & $\mathbf{L}$ & $\begin{array}{c}\text { Management accountant's role in } \\
\text { sustainability accounting and } \\
\text { reporting }\end{array}$ & & 1.000 \\
\hline I1 & No involvement in sustainability accounting and reporting & 0 & & L1 & Bean counter & 0 & \\
\hline I2 & Low involvement in sustainability accounting and reporting & 0 & & L2 & Business partner & 2 & \\
\hline I3 & Involvement in sustainability accounting and reporting & 6 & & L3 & Other & 21 & \\
\hline I4 & High involvement in sustainability accounting and reporting & 15 & & & Total & 23 & \\
\hline \multirow[t]{2}{*}{ I5 } & Not specified & 2 & & & & & \\
\hline & Total & 23 & & & & & \\
\hline
\end{tabular}

The third category, "Jurisdiction" (C), serves to indicate whether literature on the topic under investigation is focused on one organization, one nation (national), or on several nations (supra-national). This category was drawn from the original classification scheme by Guthrie et al. [37] based on seven attributes. In our paper, the attributes "national" and "supra-national" are sub-classified into "general", "industry", and "organizational", 
depending on their focus. For example, the "general" attribute contains papers that do not have an empirical basis, such as commentaries and literature reviews (supra-national general) or papers exploring specific nations, regions, and networks (national general). This unit of analysis clarifies whether this stream of literature mostly provides commentaries on the topic or instead, focuses on specific organizational settings, industries, or nations.

The fourth category refers to the organizational focus (D) and was also drawn from Guthrie et al. [37]; it supports our understanding of if and how the involvement of management accountants in sustainability accounting and reporting can depend on specific organizations' characteristics, such as publicly listed companies, public or private organizations, and not-for-profit organizations. Differently from Guthrie et al. [37], however, we have not divided private companies into SMEs and large enterprises, but included them under the same attribute, because we do not have expectations regarding a significant number of publications referred to large companies rather than to SMEs.

The fifth category, "Research method" (E), identifies the different research methods adopted by the authors. The taxonomy applied is based on the one proposed by Guthrie et al. [37] and Dumay et al. [30], but with the addition of the attribute "mixed methods" to include publications adopting both qualitative and quantitative research methods (e.g., surveys and interviews).

The five categories described so far were drawn from previous SLRs, while the five that follow were developed ad hoc. The common purpose of these next units of analysis is to delve more in-depth into management accountants' role in sustainability accounting and reporting.

The sixth category (F) refers to the sustainability definition adopted in the publications analyzed. As the notion of sustainability encompasses the environmental, social, and economic dimensions-the so-called triple bottom line [38,39]—we adopt this unit of analysis to shed light on which dimensions of sustainability the studies are specifically centered.

The seventh category $(G)$ focuses on what we call "Sustainability accounting and reporting focus" and it is referred to the internal or external orientation of sustainability accounting and reporting. It is classified into three attributes: external, internal, and both. As regards the external focus of sustainability accounting and reporting, previous studies show that sustainability information can be produced in the goal of "fulfilling stakeholder expectations and serving information requirements by external parties" [7] (p. 832). Burritt and Schaltegger [7] call it the "outside-in" approach driving sustainability accounting because its main objective is the disclosure of sustainability information useful to various external stakeholders. In an internal focus, instead, sustainability accounting is seen as "the process for information collection and communication to support internal decision making to implement corporate sustainability" [7] (p. 832). The authors call this orientation the "inside-out" approach because the organizations themselves are interested in the definition and implementation of their strategy through sustainability measurement and management; in fact, the main receivers of sustainability reports are managers who use sustainability information in their decision-making processes. The third attribute relates to the dual focus towards both external disclosure as well as internal measurement and management of sustainability information. Through this unit of analysis, we can understand whether sustainability accounting and reporting is an organizational practice devoted to the disclosure of sustainability information and, thus, primarily to meet external parties' needs or whether it is oriented towards the management of sustainability in order to help managers carry out a company strategy.

Categories eight $(\mathrm{H})$ and nine (I) refer to present and future involvement of management accountants in sustainability accounting and reporting. First, by focusing on their current involvement, we understand if and to what extent management accountants are actively involved in sustainability accounting and reporting. Similarly, the subsequent unit of analysis serves to focus on future and potential involvement in order to understand if 
and to what extent management accountants will be or should be involved in sustainability accounting and reporting in the future.

The 10th category (L) refers to the management accountant's role in sustainability accounting and reporting. Literature on management accountants identifies two main archetypes used to describe the management accountant in terms of his/her role within organizations: "bean counter" and "business partner". The former identifies a management accountant who is involved in "recording, data inputting and reporting tasks" [40] (p. 1188), often with the negative connotation of a "narrow accountant" [41] (p. 437). Conversely, the business partner archetype is associated with a management accountant who possesses "the willingness and ability [ ... ] to provide more added value to the management (decisionmaking and control) of the companies" [42] (p. 100). Therefore, we decided to apply the attributes "bean counter", "business partner", and "other". We used the third attribute to designate those studies that do not explicitly refer to the first two archetypes. It is worth highlighting that we based our coding on what was explicitly expressed in the papers to avoid any misunderstanding that could bias our results. This unit of analysis is particularly important because it can help us identify the type of roles management accountants play in relation to sustainability accounting and reporting. For example, if management accountants are defined as business partners, then they are expected to provide valuable support to the management team. Therefore, we can understand if and how management accountants can contribute to the diffusion of sustainability accounting and reporting and to the promotion of sustainability-oriented decision processes within companies.

\subsection{The Coding of the Publications and Its Reliability}

According to Massaro et al. [19], to ensure reliability, we applied the Krippendorff's alpha (K-alpha) inter-coder reliability test as a reliability measure. Reliability measures can help researchers to assess the quality of coding and reduce mistakes and personal bias. Furthermore, they can help researchers prove that their data: "(a) have been generated with all conceivable precautions in place against known pollutants, distortions and biases, intentional or accidental, and (b) mean the same thing for everyone who uses them" [43] (p. 267). According to the K-alpha test, authors can "rely on variables with reliability above $\mathrm{a}=0.800$; consider variables with reliabilities between 0.667 and $\mathrm{a}=0.800$ only for drawing tentative conclusions" [43] (p. 325).

Two authors independently coded the 23 publications in separate Excel spreadsheets. We used the software " $R$ " [44] and the library "irr" [45] to test the reliability of our coding. The results show a K-alpha higher than 0.800 for all units of analysis, meaning that the results are reliable; the third author solved any final discrepancy in coding. Results obtained from the K-alpha test are summarized in Table 3.

\subsection{The Literature Review Validity}

In this step of the SLR, according to Massaro et al. [19], we tested the literature review validity to verify the accuracy of the findings so far achieved; in particular, we verified the internal and the external validity of our SLR.

As regards the internal validity, we tested a first draft of the analytical framework, including five categories (A, B, C, D, and E), on five randomly selected studies in our dataset to verify whether the units of analysis we had chosen led to valid findings. From this small group of publications, we also identified the elements needed for a deeper examination. We expanded the framework by adding five additional units of analysis (F, G, H, I, and L), which provided us with more detailed information about the literature in question. The fact that we expanded the analytical framework after analyzing five publications shows how the implementation of the SLR method is "fluid" [19] (p. 772). In this case, we added new units of analysis, aware that an "initial analysis uncovers new and relevant attributes" [19] (p. 772). Finally, we used the analytical framework for coding all publications. 
Regarding the external validity, which concerns the possibility that the results of the study could be representative of this stream of research, we did not limit our search in Scopus to a specific document type. We looked for all possible types of publications, according to Scopus taxonomy, such as articles, articles in press, proceedings, book chapters, editorials, short surveys, and so on. Therefore, despite the limited literature on this specific topic, our dataset can be considered representative of the available literature on this theme. As Figure 1 illustrates, our final dataset is composed of 18 articles, 4 book chapters, and 1 short survey.

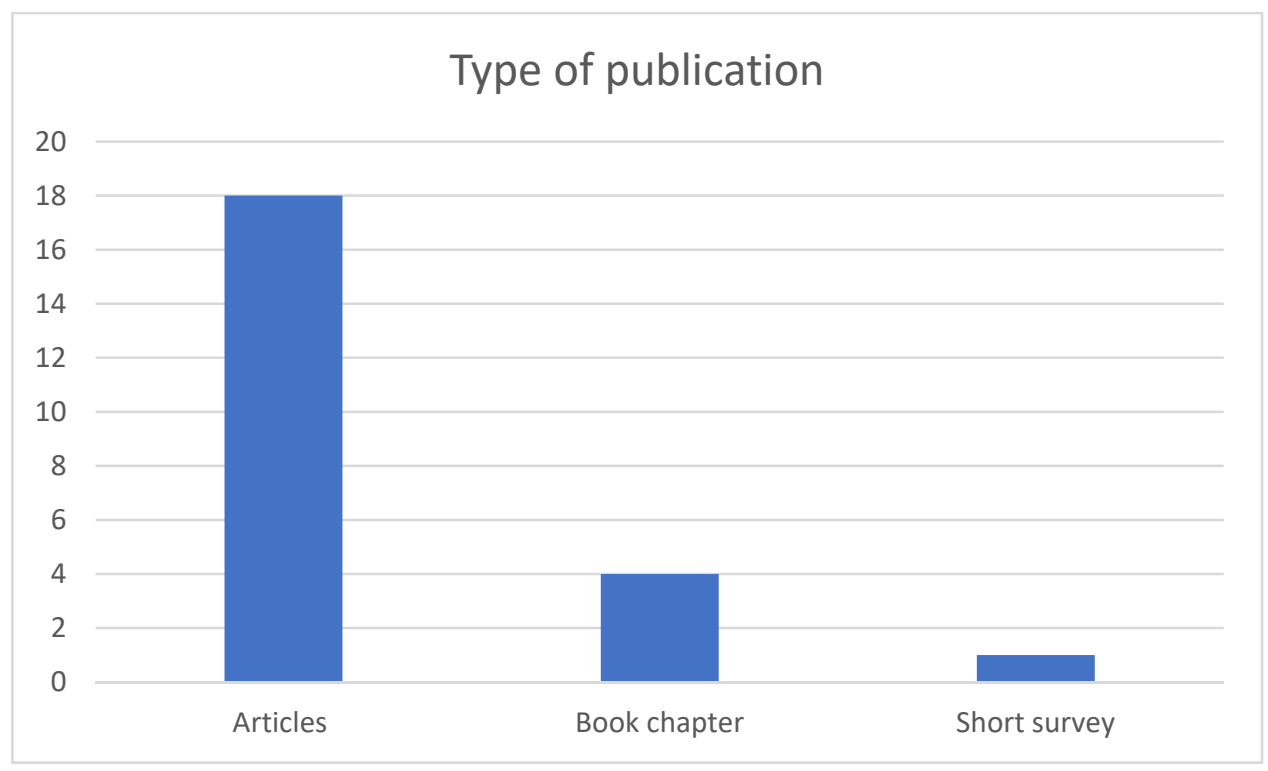

Figure 1. Type of publication.

As regards the articles, Table 4, below, shows their distribution among journals. The distribution is very fragmented; while Sustainability Accounting, Management, and Policy Journal published three papers and Accounting Forum, Accounting, Auditing, and Accountability Journal, and Pacific Accounting Review published two papers, the remainder of the journals published only one article each. Overall, it is possible to observe that a higher interest in this topic is shown by journals devoted to sustainability and accounting themes.

Table 4. Distribution of articles in journals.

\begin{tabular}{cc}
\hline Source Title & Number \\
\hline Accounting Forum & 2 \\
Accounting Horizons & 1 \\
Accounting, Auditing and Accountability Journal & 2 \\
Journal of Accounting and Organizational Change & 1 \\
Journal of Cleaner Production & 1 \\
Journal of Legal, Ethical and Regulatory Issues & 1 \\
Journal of Sustainable Finance and Investment & 1 \\
Pacific Accounting Review & 2 \\
Revista de Contabilidad - Spanish Accounting Review & 1 \\
Social and Environmental Accountability Journal & 1 \\
Social Responsibility Journal & 1 \\
Studies in Managerial and Financial Accounting & 1 \\
Sustainability Accounting, Management and Policy Journal & 3 \\
\hline
\end{tabular}

In addition, we placed no temporal restrictions in Scopus and our final dataset contains studies published between 2001 and 2020. As shown in Figure 2, below, despite the 
limited numbers of publications, an increasing interest in the nexus between sustainability accounting and reporting and the role of management accountants is evident.

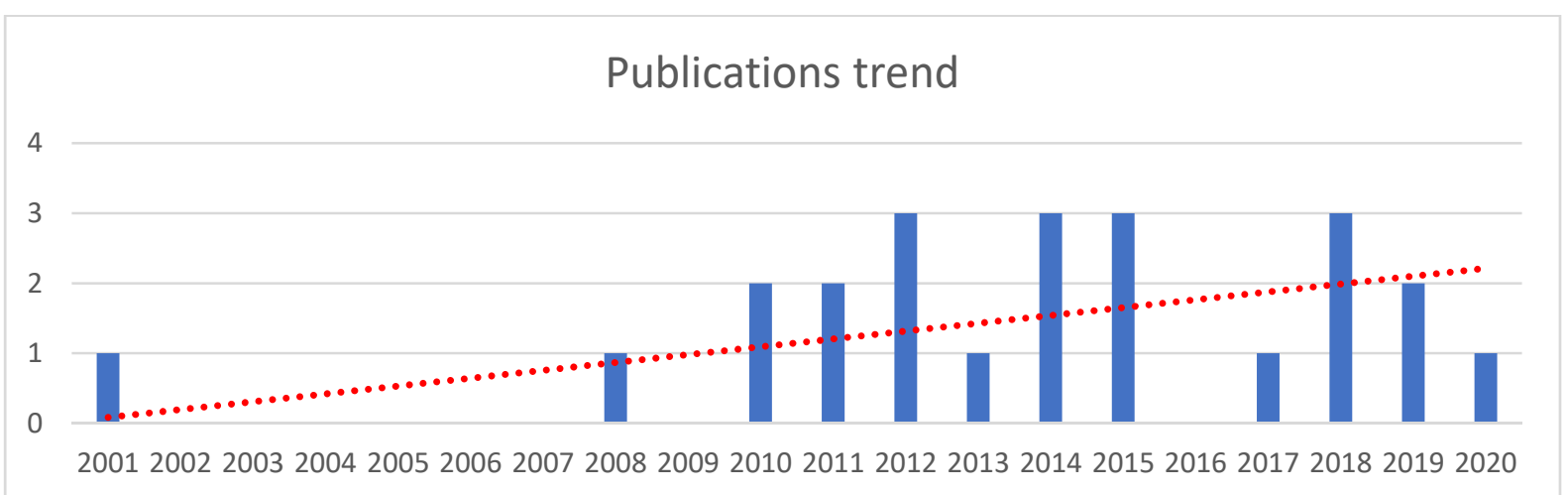

Figure 2. Publication trend.

\section{Findings}

The following sections present results to answer RQ.1 "How is research for inquiring into the role of management accountants in sustainability accounting and reporting developing?" and RQ.2 "What is the focus and critique of the research on the role of management accountants in sustainability accounting and reporting?". They are structured according to the categories of the analytical framework. It is important to underline that valuable information to answer RQ.1 has been also gathered through the analysis of the publications' impact (Section 3.4), trend, distribution among journals, books, etc. (Section 3.7).

\subsection{Author Type}

The category "Author type" (A) includes three attributes: A1 Academic(s), A2 Practitioner(s) and consultant(s), and A3 Academic(s), practitioner(s), and consultant(s). All of the studies in our SLR were written by academics, except for one article [46] that was authored by a practitioner. In 2008, Lewis was an assistant director in the Policy and Technical Directorate of the Chartered Institute of Public Finance and Accountancy (CIPFA).

Of the 23 publications analyzed, 10 were co-authored, with five studies written by two authors, four by three authors, and one by four authors. In addition, our findings show that Low, Tingey-Holyoak, and Zvezdov wrote two publications, while Schaltegger authored three papers.

\subsection{Location}

The "Location" (B) criterion includes six attributes: B1 Africa, B2 The Americas, B3 Asia, B4 Europe, B5 Oceania, and B6 Other. Table 3 shows that Oceania is the most studied geographical area with eight papers e.g., [47-49], followed by Europe with five papers e.g., [50,51]. Within Oceania, most of the studies focus on Australia and New Zealand. Interestingly, a common aspect of some studies located in both of these countries is their attention to the environment and natural resources, like carbon or water [52,53]. The fact that Oceania boasts the highest number of publications seems to confirm the strong interest and the relevant role that this region has been playing and still plays in the development of studies related to business and supplementary reporting, such as the Intellectual Capital Report [37,54] and the Integrated Report [55-58] and in the measurement, management, and disclosure of intangibles and non-financial capitals.

Within Europe, France, Spain, Germany, and the UK are the most explored geographical areas. The remaining regions are under-investigated with only one article for each continent. It is worth noting that some countries, such as China and the United States, contribute little to this research field, despite the high environmental and social impact of their economies. 
Lastly, seven articles were coded under the attribute "Other" e.g., [59-61] since they did not focus on a specific country or geographical area. As we will see next, several articles included in the sample are commentaries or essays that offer observations without focusing on a specific context.

\subsection{Jurisdiction}

In the category "Jurisdiction" (C), we classify publications referring to the following attributes: C1 Supra-national/International/Comparative-General, C2 National-General, and C3 One organization. Attributes $\mathrm{C} 1$ and $\mathrm{C} 2$ have both been further sub-classified into: C1.1 Supra-national/International/Comparative-Industry, C1.2 Supra-national/International/Comparative-Organizational, and C2.1 National-Industry, and C2.2 NationalOrganizational.

Our analysis results show that seven publications fall into C1 e.g., [34,36,60]; they were not the product of empirical analysis. Two publications fall into C2 [33,62]; while Ballou et al. [33] explored how management accountants could support sustainability initiatives in the context of an association, i.e., the Corporate Responsibility Officer's Association, Lodhia [62] focused on the Sustainable Development Bill, an environmental legislation for Fiji, and its influence on management accountants. C3 includes three publications focused on one organization [35,63,64]; Fraser [35] studied the case of a local city council, while Egan and Tweedie [64] focused on a large company group, and Fernández Chulián [63] circumscribed the study to a Spanish university.

Looking at the specific sub-attributes, no paper met the criteria of C1.1, while two papers fell into $\mathrm{C} 1.2[51,65]$ as the focus was on companies belonging to different industries located in Germany and the UK. As regards the sub-attributes of C2, five publications fall into C2.1 e.g., [46,53] with a focus on specific industries located in one nation. Four publications are included in C2.2 e.g., [48,66]; they are centered on organizations belonging to different industries but located in the same nation.

One overriding observation that emerged is that most of the publications in our dataset do not have an empirical underpinning; these studies, national and supra-national, provide insights about the role of management accountants in sustainability accounting and reporting and highlight some practical implications about their involvement in this area. At the industry level, five papers have analyzed organizations belonging to a specific industry at a national level, while no studies explore a specific industry in different national contexts. Finally, only three studies have focused on a single organization; organizations belonging to different industries have been investigated both at the national and supranational levels of analysis.

\subsection{Organizational Focus}

The category "Organizational focus" (D) consists of five attributes: D1 Publicly listed companies, D2 Private companies, D3 Public sector, D4 Not-for-profit sector, and D5 General/Other.

The publications in the dataset fall into sub-categories D2, D3, and D5. Three publications focus on D2 "Private companies", i.e., professional accounting firms [52], professional services firms [53], and a firm operating in the food industry [64]. Public sector organizations are the subject of five publications e.g., $[35,46]$ belonging in the D3 attribute. Although we did not divide the public and private sectors into sub-attributes within the analytical framework, we took note that two papers analyzing the public sector focus on local government institutions [35,49], and two papers focus on the university context [47,63]. As regards universities, Botes et al. [47] investigate the state of the art of accounting education in relation to sustainability in New Zealand universities, showing that sustainability issues are not integrated enough in the accounting courses and that "sustainability education is not in sufficient depth" [47] (p. 116) to the extent that many would-be management accountants leave accounting programs without the appropriate comprehension of the concept of sustainability. Similarly, Fernández Chulián [63] highlights the need for change 
in the accounting education of future management accountants and explores the possibility of including sustainability accounting and reporting in accounting programs in Spanish universities.

We found that most of the studies (15 out of the 23 papers) belong in D5, which represents a "residual" attribute for publications that do not fit any of the other specific attributes. D5 includes studies that have to do with different types of organizations, such as both public and private organizations and/or listed and not listed companies e.g., [48,67]. Moreover, this attribute includes papers that are concerned with organizational issues without referring to a specific type of organization $[33,51,65]$ as well as publications that have no organizational focus e.g., [59,60,62].

In our analysis of the organizational focus of the 23 publications, we expected to find studies on both publicly listed companies - which are often at the forefront of sustainability issues because of regulatory requirements - and not-for-profit organizations-which by their nature are committed to the collective social good. Instead, no papers in our dataset focused on either of these two kinds of entities.

\subsection{Research Method}

The "Research method" category (E) includes six attributes: E1 Case/Field study/ Interviews, E2 Content analysis/Historical analysis, E3 Survey/Questionnaire/Other empirical, E4 Mixed methods, E5 Commentary/Normative/Policy, and E6 Literature review.

The most often-used research method (eight publications) is E5 "Commentary/Normative/Policy" e.g., [32,34,59]. The next most common are E1 "Case/Field study/Interviews" and E3 "Survey/Questionnaire/Other empirical" (five publications each). In E1, for example, Egan and Tweedie [64] use the case study method focusing on a large Australian company in order to investigate how management accountants can contribute to corporate sustainability. In E3, Ballou et al. [33], for example, conducted a survey completed by 178 members of the Corporate Responsibility Officer's Association to explore how accountants can promote the strategic integration of sustainability initiatives.

In our sample of 23 publications, four papers use mixed methods and fall into E4 e.g., [47,48]. For example, Mistry et al. [48] conducted surveys and semi-structured interviews with management accountants to investigate their perceptions about their role in accounting for sustainable development within organizations. Finally, Çalişkan [36] is the only author who carries out a literature review analyzing the role of accounting and accounting professionals in sustainability. No papers employ historical and content analysis as the research method.

In sum, our results highlight that nine papers adopted a descriptive and normative approach, typical of commentaries, a method that prevailed in the early years of the time period considered. The number of empirical papers has increased over the last few years, and both qualitative and quantitative methods have been applied.

\subsection{Sustainability Definition}

We divided the category "Sustainability definition" (F) into seven attributes: F1 Environmental-Social-Economic, F2 Environmental-Social, F3 Environmental-Economic, F4 Social-Economic, F5 Environmental, F6 Social, and F7 Economic. The publications in the dataset fall into attributes F1, F2, and F5.

From the publication of the Brundtland Report [68], the last three decades have seen a constant interest in the concept of sustainability, mainly understood as the balance between environmental protection, social responsibility, and economic goals, summarized by Elkington as the "triple bottom line" [38,39]. The results of our SLR confirm this trend, with 12 studies coded into the F1 attribute, meaning that more than $50 \%$ of the publications are in line with the most accredited and widely accepted definition of sustainability, which combines the environmental, social, and economic dimensions e.g., $[47,48,50]$. 
The next most-populated attribute, F5, contains seven papers that focus on the environmental dimension e.g., $[62,64,67]$ and which, albeit with different nuances, examine the role of management accountants in measuring and disclosing company impacts on air, water, and, more generally, natural resources. For example, Burritt and Tingey-Holyoak [52] focus on carbon accounting; similarly, Tingey-Holyoak and Pisaniello [53] explore the topic of water accounting knowledge. It is not surprising that many papers focus on the environmental dimension considering that "an increasing recognition of the impact of humans on the environment has led to a radical requestioning of traditional economic, ethical, and accounting assumptions" [32] (p. 124) and that the environment itself is often described as "one of the few silent groups of stakeholders" [60] (p. 213). In this regard, given the importance of environmental issues for organizations and society, Jones [32] develops a theoretical framework for environmental accounting and reporting that challenges the traditional accounting paradigm. In addition, the author examines the implications of this theoretical framework for management accountants and organizations.

Of the three dimensions - environmental, social, economic - the environmental dimension is the only one that is analyzed separately with respect to the social and economic dimensions. The remaining four papers fall into F2 and focus on both the environmental and the social dimensions, delving into the role of management accountants in social and environmental accounting; Tilt [34], for example, investigates the involvement of management accountants in Corporate Social Responsibility (CSR).

\subsection{Sustainability Accounting and Reporting Focus}

The category "sustainability accounting and reporting focus" (G) consists of three attributes: G1 Internal: Measurement and management, G2 External: Disclosure, and G3 Internal and external: Measurement, management, and disclosure. The most commonly found orientation is G3 "Internal and External: Measurement, management, and disclosure", which characterizes 13 papers e.g., [50,51]. The rest of the publications are evenly split between internal and external focus, with five papers addressing measurement and management e.g., [35,64] and five papers exploring disclosure e.g., [46,62], classified in G1 and G2, respectively.

The publications in our dataset generally do not focus on a specific accounting tool, with a few notable exceptions. Some studies investigate tools employed for disclosure goals, such as sustainability reporting [46,47,49] and integrated reporting [59]. As for tools used for sustainability measurement and management, Fraser [35] focuses on the application of a Sustainability Assessment Model (SAM) in a city council, while Egan and Tweedie [64] study the involvement of management accountants in sustainability initiatives within an Australian company where a sustainability report was introduced as a form of internal business reporting. Finally, in the context of both external and internal focus, Çalışkan [36] (p. 258) highlights that sustainability reports are "the main product of accounting systems used by both internal and external stakeholders to evaluate the result of a corporation's activities".

Overall, the results of this unit of analysis show that neither an inside-in nor an outside-out approach [7] predominate, as sustainability accounting and reporting seem relevant both for disclosure purposes and for managerial decision support.

\subsection{Management Accountants' Current Involvement in Sustainability Accounting and Reporting}

The category "Management accountant's current involvement in sustainability accounting and reporting" $(\mathrm{H})$ includes five attributes: H1 No involvement in sustainability accounting and reporting, H2 Low involvement in sustainability accounting and reporting, H3 Involvement in sustainability accounting and reporting, H4 High involvement in sustainability accounting and reporting, and H5 Not specified.

In our sample, only Lodhia [62] reports no current involvement of management accountants and eight papers do not specify the current involvement of the management accountant in sustainability accounting and reporting e.g., $[46,59,61]$. The analysis also reveals 
that nine publications report a current low involvement in sustainability accounting and reporting e.g., [34,49,51]. In particular, these studies highlight that non-accountants are more involved in sustainability accounting and reporting than accountants are e.g., [51,64,69]. In this regard, several scholars have pointed out that professionals such as engineers [53], general or middle managers, sustainability managers [51,65], or environmental managers [64] are often in charge of sustainability accounting and reporting within organizations. Schaltegger and Zvezdov [51] found that sustainability and general managers identify, create, and provide sustainability information, while the involvement of management accountants is related to the definition of indicators and the provision of information to decision makers at the top management level. Therefore, it appears that management accountants do not play a role in decisions about what sustainability information should be collected and created. This may be because, as observed by Schaltegger [69], conventional management accounting systems are not able to provide sustainability information and a new range of measurement and management tools specifically addressed to sustainability issues have been developed and used by non-accountants; these tools reflect the specific needs of different departments within organizations. For instance, marketing managers "are particularly interested in physical information (e.g., on environmental impacts) but much less in monetary sustainability information (e.g., costs of pollution prevention or savings derived from energy efficiency measures)" [69] (p. 280), while finance managers collect and use quantitative and monetary sustainability information [69].

Williams [49] suggests that the low involvement of management accountants could be due to the current inadequacy of their skill sets; management accountants need to be skilled in sustainability in order to be able to "measure, evaluate, record, interpret, and report organisational sustainability information" [49] (p. 282). In this regard, Egan and Tweedie [64] show that management accountants also lack the mindset needed to support sustainability practices and struggle to find a common vocabulary with other organizational actors, such as engineers. The authors show that when management accountants engage in sustainability initiatives, they appear reluctant to embrace innovations: they support non-accountants in the data collection and reporting, but they do not work creatively with colleagues of other Departments to develop innovative accounting solutions.

Finally, three studies note a current involvement of management accountants in sustainability accounting and reporting $[48,60,67]$ and two publications highlight their current high involvement [35,53]. Idowu [60] commented that management accountants are involved in ensuring that organizations are socially responsible through the control of costs and benefits associated with social and environmental issues. In particular, the author focused on Social and Environmental Accounting (SEA) and commented on some management accounting techniques useful to support short- and long-term decisions about sustainability. In this vein, Margerison et al. [67] found that, in China, management accountants are embracing environmental accounting in an effort to broaden their traditionally narrow specialization. By using surveys and interviews, Mistry et al. [48] found that, although they do not use environmental management accounting systems, management accountants employed in large organizations are involved in accounting for sustainable development by supporting the decision-making process of upper-level management. In contrast, management accountants employed in SMEs play a more limited role in sustainability accounting and reporting and they deal with traditional activities such as "producing managerial reports, preparing cost benefit analysis, dispatch schedules, etc." [48] (p. 129). In his study, Fraser [35] found that the involvement of management accountants in the application of a Sustainable Assessment Model (SAM), which is "an accounting technology developed to incorporate sustainability considerations into organizational decision-making and, potentially, accountability processes" [35] (p. 509), provided credibility to the project because the SAM was framed as "an extension of a legitimate accounting tool" [35] (p. 527).

In sum, we observe that management accountants are not highly involved in sustainability accounting and reporting within organizations, at least in the current scenario. 
Sustainability accounting and reporting appear to be more practiced by non-accountants, such as sustainability managers or general managers, while management accountants' involvement appears to be marginal. However, some studies have reported the involvement of management accountants in sustainability accounting and reporting; these studies have mainly focused on the environmental dimension of sustainability and have illustrated that management accountants can support decision making processes through the application of environmental accounting tools, even if their use remains somewhat limited.

\subsection{Management Accountants' Future/potential Involvement in Sustainability Accounting and Reporting}

The category "Management accountant's future/potential involvement in sustainability accounting and reporting" (I) explores the same basic theme of the previous one $(\mathrm{H})$ but with a different time perspective: the future. It also includes five attributes: I1 No involvement in sustainability accounting and reporting, I2 Low involvement in sustainability accounting and reporting, I3 Involvement in sustainability accounting and reporting, I4 High involvement in sustainability accounting and reporting, and I5 Not specified.

Analysis results revealed that only 2 publications do not specify the future involvement of management accountants, 6 studies foresee a future involvement of management accountants, and 15 studies point to a high future involvement in sustainability accounting and reporting. Generally speaking, the publications that observe an involvement of management accountants claim that they can play a role in sustainability measurement and management in the future e.g., [36,47,52,61,62]. In this regard, Schaltegger [69] suggests that the future involvement of management accountants could concern the coordination and organization of different types of sustainability information developed by managers and its incorporation into the overall management accounting system of the organization.

It is noteworthy that three studies are focused on sustainability and accounting education and they all foresee a potential future involvement of management accountants, which would depend on their training in sustainability accounting and reporting $[47,50,63]$. In this regard, referring to water accounting, Tingey-Holyoak and Pisaniello [53] suggest that it would be necessary for accountants and engineers to create, standardize, and share knowledge based on their respective domains of expertise. This point has also been underscored by Burritt and Tingey-Holyoak [52] and Çalışkan [36]. In particular, Çalışkan [36] (p. 263) suggests that future management accountants need to be "equipped with the core knowledge of environmental engineering as a specialized profession to handle the technical accounting problem that is related to sustainability". Overall, it seems that the future involvement of management accountants in sustainability accounting and reporting will depend on their ability to broaden their existing/traditional domain of expertise by acquiring knowledge and developing new skills and competencies traditionally pertaining to other fields of expertise. This observation echoes the phenomenon, identified and studied in the accounting literature, of management accountants' "hybridization", defined as "the enlargement in the set of practices and legitimated competencies which make up the domain of a specific expertise" [70] (p. 147). It seems that management accountants should expand their competencies to include aspects of environmental engineering to calculate costs related to the consumption of environmental resources.

\subsection{Management Accountants' Role in Sustainability Accounting and Reporting}

The category "Management accountant's role in sustainability practices" (L) includes three attributes: L1 Bean counter, L2 Business partner, and L3 Other. As explained in the section dedicated to the analytical framework (Section 3.5), we based our coding on what the authors explicitly declared in their manuscripts about management accountants' role in order to avoid the risk that our understanding and interpretations could bias the results.

Our results show that no papers identify a bean counter's role, only two papers refer to a business partner's role, while 21 papers provide some description of the management accountant's role in sustainability accounting and reporting without referring to the traditional archetypes. 
Hoang [59] and Oyewo [66] specifically refer to a business partner role for management accountants. Hoang [59], who focused on how Boards of Directors may raise awareness on ESG risks via corporate reporting, stated that the adoption of the Integrated Report gives management accountants an important role to play in providing ESG information to stakeholders. Moreover, Hoang [59] (p. 65) calls for future research on management accountants as business partners, because "the rising awareness of ESG risks requires new knowledge and experience in both financial and non-financial". Oyewo [66], in turn, who used questionnaires to collect the views of 131 senior accounting/finance officers from Nigerian firms, found that the presence of management accountants with specialized skills allows management accounting practices to support corporate sustainability, prompting the author to call for "accountants in business" [66] (p. 27). The 21 papers that provide some descriptions of management accountants' role in sustainability accounting and reporting do not explicitly refer to the traditional archetypes. So, while there is a consensus on the fact that management accountants should or may play a role in sustainability accounting and reporting, there is "uncertainty regarding the role that accountants should play" [47] (p. 117).

In this regard, Schaltegger and Zvezdov $[51,65]$ argue that "accountants are involved in sustainability accounting in a way that has not been investigated in literature to date" [51] (p. 350). In particular, they highlight how management accountants may act as "gatekeepers", which they also defined as a "brokerage role". A similar type of role is also posited by Egan and Tweedie [64]. In such a role, Schaltegger and Zvezdov [51] stated that management accountants would select sustainability information, produced by managers, and define the indicators to be presented to the top management to be used in their decision-making processes. They described it in the following way: "this role of accountants transforming and transporting information between functional specialists, departments and top management can be seen as information brokerage. Brokerage is the act of facilitating exchange. [ ... ] accountants as information brokers could support the uptake of sustainability issues and bring the importance of sustainability performance to the immediate attention of senior management" [51] (p. 339).

Overall, the literature on management accountants' role in sustainability accounting and reporting does not resort to the traditional management accountant descriptors. Their new role as "gatekeepers" is emerging in an intermediate position between internal producers of sustainability information and top management; thus, management accountants could play a role in facilitating and supporting information flows within organizations.

\section{Discussion, Future Research Directions, and Conclusions}

The literature review carried out in the previous sections shows that, despite the limited number of papers and their fragmented distribution in various journals, academic interest in exploring the role played by management accountants in sustainability accounting and reporting is growing. In terms of geographic distribution, Oceania is the most studied region, thus confirming this area's strong interest and continued role in the development of research related to the measurement, management, and disclosure of intangibles and non-financial capitals. In order to have a broader perspective, it could be interesting to conduct a more in-depth investigation of the European area, which has, so far, been the object of only a modest number of empirical investigations; it would also be interesting to extend the analysis to China and the U.S., which remain unexplored. Our review also highlights that empirical investigations are still scarce, and this seems to confirm that, while the relevance of this research field has been recognized, there is the need to delve more deeply into this topic. In this regard, the literature review shows that our knowledge about the role of management accountants in sustainability accounting and reporting within private companies and public organizations is limited. To date, no study has explored this topic in publicly listed companies or in not-for-profit organizations, which, by their very nature, should be at the forefront of sustainability debates. 
Our findings reveal that many studies of our dataset focus on the measurement and management of sustainability information and, thus, on the relevance of sustainability information for planning, controlling, and for organizations' decision-making process. However, those who traditionally are in charge of these tasks and responsibilities, i.e., management accountants, are less involved in sustainability accounting and reporting than non-accountants are. More specifically, their role mainly involves managing sustainability information flows between the internal producers of this information and top management, rather than actually identifying relevant data and producing information. As observed by some authors, this may be attributable to the ad hoc development of measurement and management tools, within specific departments, to address sustainability issues, given that traditional management accounting systems are inadequate for providing sustainability information. In addition, our findings show that neither the organizational characteristics of the company in which management accountants are employed, nor the industry to which these companies belong to, influence their limited involvement in sustainability accounting and reporting.

Despite their current limited engagement, management accountants are expected to be more involved in sustainability accounting and reporting in the future since they are the ones who have the proper accounting competencies to support the diffusion of sustainability accounting and reporting within organizations. Nonetheless, management accountants' potential future involvement seems also to be conditional on their ability to acquire competencies and skills in sustainability; in this regard, universities could play a pivotal role. Finally, the present review also offers some insights on the taxonomy related to the role of management accountants in this field. Currently, it is not fully clear how to best describe the role management accountants can or could play in sustainability accounting and reporting. Traditional archetypes developed in the accounting literature on management accountants' role, i.e., bean counter and business partner, are not employed nor, perhaps, are they suitable to describe their role in sustainability accounting and reporting; fairly new, instead, the term "gatekeepers" has emerged in the accounting literature and has gained some attention.

The primary focus of this section is to critically discuss the main findings of the SLR in order to answer RQ.3: "What future avenues of research on the role of management accountants in sustainability accounting and reporting can be identified?". In the following sections, we offer further reflections on the current state of the literature and highlight future avenues of research that emerge from our study. Our discussion includes management accountants' involvement and role in sustainability accounting and reporting, the harmonization and standardization of sustainability information and implications for management accountants, and the role of education in sustainability accounting and reporting for future management accountants.

\subsection{Management Accountants' Involvement in Sustainability Accounting and Reporting}

The SLR shows that the current involvement of management accountants in sustainability accounting and reporting is, in most cases, marginal. However, all of the publications in our dataset suggest a potentially relevant, future involvement of management accountants in sustainability, meaning that a high involvement of management accountants in sustainability accounting and reporting is needed and should be fostered.

Table 5, below, is a pivot table resulting from the relationship between the current and the future or potential involvement of management accountants in sustainability accounting and reporting. As outlined in the papers included in our SLR, 12 papers that had reported a not specified, an absent, or a low current involvement of management accountants in sustainability accounting and reporting call for their future high involvement. In this regard, Schaltegger and Zvezdov [51] (p. 353) suggest that "the main implication for future research is investigating how accountants could be more strongly involved in sustainability accounting and reporting". 
Table 5. Current and potential involvement of management accountants in sustainability accounting and reporting.

\begin{tabular}{|c|c|c|c|c|}
\hline & $\begin{array}{l}\text { Potential/Future } \\
\text { Involvement }\end{array}$ & & & \\
\hline $\begin{array}{c}\text { Current } \\
\text { Involvement }\end{array}$ & $\begin{array}{l}\text { High involvement in } \\
\text { sustainability accounting and } \\
\text { reporting }\end{array}$ & $\begin{array}{l}\text { Involvement in sustainability } \\
\text { accounting and reporting }\end{array}$ & $\begin{array}{c}\text { Not } \\
\text { specified }\end{array}$ & Total \\
\hline $\begin{array}{l}\text { High involvement in sustainability } \\
\text { accounting and reporting }\end{array}$ & 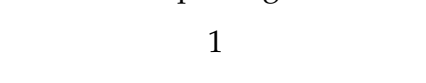 & - & 1 & 2 \\
\hline $\begin{array}{l}\text { Involvement in sustainability } \\
\text { accounting and reporting }\end{array}$ & 2 & 1 & - & 3 \\
\hline $\begin{array}{l}\text { Low involvement in sustainability } \\
\text { accounting and reporting }\end{array}$ & 7 & 1 & 1 & 9 \\
\hline $\begin{array}{l}\text { No involvement in sustainability } \\
\text { accounting and reporting }\end{array}$ & 1 & - & - & 1 \\
\hline Not specified & 4 & 4 & - & 8 \\
\hline Total & 15 & 6 & 2 & 23 \\
\hline
\end{tabular}

In this scenario, it is also important to underscore how limited empirical research has been up to now; therefore, it could be interesting to expand, in breadth and depth, our knowledge on the actual involvement of management accountants in sustainability accounting and reporting. On the one hand, this can be achieved by conducting empirical research on a wider scale, which would also provide a better and more detailed understanding of the current involvement of management accountants; it would also help us to see if there is a relationship between their involvement and certain company characteristics, such as corporate size (as already explored by Mistry et al.) [48], organizational structure, or sector, among others. On the other hand, future research could also delve into those situations in which management accountants have a high involvement in sustainability and accounting practices by conducting exploratory single or multiple case studies, which may help understand why and how management accountants are, or could be, be involved in sustainability accounting and reporting.

\subsection{The Role of Management Accountants in Sustainability Accounting and Reporting}

The SLR reveals that research on the role of management accountants in sustainability accounting and reporting has found a new conception of this role, i.e., that of "gatekeepers" of sustainability information $[51,61,64,65]$. The role of gatekeeper, also defined by Schaltegger and Zvezdov [51] as a "brokerage role", includes selecting sustainability information, frequently produced by sustainability or functional managers, overseeing its exchange and diffusion among the different managers, and directing towards the top management. In this way, management accountants are central to integrating sustainability in the managerial decision-making process and to favoring the uptake of sustainability practices by managers. If we consider the ample literature produced over the years on the different roles that management accountants may play, this role seems to be new. More specifically, even if Lantto [71] identified the role of management accountant as "brokers" in 2014, she ascribed it a different nuance. In her case study, Lantto [71] found that management accountants acted as brokers between the IFRS world—external parties—and the organization, "bridging boundaries between the reporting practice and the business" [71] (p. 351). Instead, in the case of sustainability accounting and reporting, management accountants act as brokers within organizational boundaries. Therefore, further research should be undertaken for an in-depth investigation into the nature and the characteristics of this role, the activities related to it, the possible criticalities a management accountant may face, and the competencies (technical and soft) that should be developed when playing this role.

As far as the traditional archetypes on management accountants are concerned (e.g., bean counter and business partner-see Section 3.5), we argue that their relevance in sustainability accounting and reporting needs to be further investigated. As a matter of 
fact, our SLR reveals that only in two articles of our dataset is there explicit mention of one of these archetypes (business partner). In this regard, it would be interesting to conduct more empirical research to explore whether and how traditional archetypes are able (or not able) to describe the role of management accountants in sustainability accounting and reporting. Considering the different effects associated with these archetypes in terms of the ability to understand the business, to innovate the management accounting system and thus, to influence the managerial decision-making process, more research on management accountants' roles could help understand the actual diffusion of sustainability accounting and reporting practices in companies, as well as its evolution.

\subsection{Management Accountants and the Harmonization of Sustainability Information}

Management accounting as an organizational practice is not an exclusive prerogative of management accountants, to the extent that, over the years, operational managers have increasingly undertaken activities traditionally pertaining to the management accounting field [72,73]. Our SLR shows that management accountants are less involved in sustainability accounting and reporting compared to non-accountants, such as engineers [53], general or middle managers, sustainability managers [51,65], or environmental managers [64].

In this regard, Schaltegger [69] (p. 280) argued that different managers (e.g., production, marketing, etc.) may "have their own specific sustainability information, methods and databases", but that the existence of this locally developed sustainability information may result in inefficiency, lack of harmonization, and incoherence of sustainability information itself, since various functional managers gather and use differently sustainability information with disparate purposes. Therefore, with a variety of professionals dealing with sustainability decisions, it becomes necessary to harmonize and standardize the collection, communication, and use of sustainability information. According to Schaltegger [69], management accountants may avoid conflicts and contradictory results by designing a comprehensive sustainability management accounting system or by fostering the integration of sustainability information within the overall management accounting system of the organization. Thus, the author encourages management accountants to further develop the coordination and integration of different types of sustainability information [69] (p. 287).

In line with this, we deem that further research is needed to better understand not only the criticalities of integrating sustainability information within the corporate management accounting and reporting system, but also how the management accountant may help overcome or reduce them. The problem of the integration of local measures in management corporate reporting is an area open to research in management accounting. Lukka [74] (p. 340) argues that "their integration does not seem an impossible task in practice since there is a potential division of labour between the two". The role that management accountants may have in promoting the harmonization and the integration of local measures into the corporate reporting and vice versa has been explored by Chiucchi $[8,14]$, who has also shown some of the characteristics that the management accountant should have to help this integration. Therefore, additional research in this direction may also help favor the harmonization and standardization of sustainability information within the corporate reporting process.

Finally, future research could investigate the phenomenon of "hybridization" [70] (p. 147), which could be driven by the introduction and development of sustainability accounting and reporting, and its consequences, in terms of professional competition. This derives, on the one hand, from non-accountants being more involved than management accountants in sustainability accounting and reporting and thus, entering the accounting field of expertise. On the other hand, in order to remain competitive and reduce the risk of being "pushed out" by other non-accountants, management accountants find themselves needing to engage in sustainability and develop new skills pertaining to other fields of knowledge, e.g., engineering. 


\subsection{Management Accountants, Sustainability and Accounting Education}

In our SLR, a growing concern regarding management accountants' education has emerged; it relates to equipping future accountants with the necessary skills and competencies to deal with sustainability accounting and reporting, which has been the object of attention in some studies e.g., $[47,50,63]$. Specifically, some national accounting education programs have been examined to understand the relevance of sustainability issues; the results show that sustainability issues are not present enough [50] and not sufficiently integrated [47] in the accounting programs. Furthermore, aspiring accountants do not seem to have an adequate understanding of the concept of sustainability when they leave accounting courses [47].

As stated by Boulianne et al. [50] (p. 313), a pivotal challenge in accounting today is "determining not only what an accountant is but also what an accountant should be". In a similar vein, Fernández Chulián [63] highlights the need for an extensive redesign of accounting programs in order to train new generations of accountants. Although not specifically focused on accounting education per se, other studies call for investigations on the role of accounting education - provided both by universities and professional external bodies-in improving management accountants' sustainability knowledge [51] and in contributing "to move away from the traditional economic focus that currently dominates accounting practice" [49] (p. 282).

Future research could further examine the reasons why current accounting education programs do not effectively provide management accountants with the necessary expertise in sustainability; therefore, it would also be interesting to explore how their effectiveness could be increased. Furthermore, it could be enlightening to look for a possible link between the low involvement of management accountants and their education, by studying if and how the sustainability skills and competencies required by organizations are covered in formal accounting programs, for example.

In conclusion, we hold that the extant literature on the role of management accountants in sustainability accounting and reporting appears still limited and that future research would clarify and enrich our understanding on the topic at stake. From the results of our SLR, we have identified some research avenues that may be interesting, from a theoretical point of view, to better understand the role and the involvement of management accountants in sustainability accounting and reporting and that could also help investigate their influence on the uptake of sustainability practices by managers.

Some of these research streams may also have practical implications. For instance, since a more relevant involvement of management accountants will depend both on their ability to broaden their traditional domain of expertise and on the role of accounting education in improving the sustainability knowledge of future generations of management accountants, educational institutions may benefit from the results of this research to design their graduate and masters' programs. Moreover, the results of the SLR would also encourage and inspire management accountants to engage in sustainability and to drive innovations by incorporating sustainability in corporate management accounting and reporting systems.

As with any piece of research, this paper has limitations. The findings observed are limited to the data analyzed and to the choices made during the process of writing this review. We documented each phase in detail, in order to make it possible to repeat and verify the undertaken procedures. In addition, future literature reviews could use other scientific databases for the search process, such as Web of Science, to compare and discuss results of different datasets. Finally, the findings of this paper are dependent on our interpretation; we therefore take responsibility for the interpretation and possible errors and/or omissions.

Author Contributions: 1. Introduction, M.S.C.; 2. Research Method, R.C.; 3. The Structured Literature Review, R.C.; 4. Findings, I.A.; 5. Discussion, Future Research Directions, and Conclusions, I.A. and R.C., and more specifically 5.1. and 5.2. I.A.; 5.3. and 5.4. R.C. All authors have read and agreed to the published version of the manuscript. 
Funding: This research received no external funding.

Institutional Review Board Statement: Not applicable.

Informed Consent Statement: Not applicable.

Data Availability Statement: Data is contained within the article.

Conflicts of Interest: The authors declare no conflict of interest.

\section{Appendix A Publications Reviewed in Chronological Order}

I. Lodhia S.K. The accounting implications of the sustainable development bill. Soc. Environ. Account. J. 2001, 21, 8-11.

II. Lewis, T. Debate: Public sector sustainability reporting - Implications for Accountants. Public Money Manag. 2008, 28, 329-331.

III. Jones M.J. Accounting for the environment: Towards a theoretical perspective for environmental accounting and reporting. Account. Forum 2010, 34, 123-138.

IV. Tilt, C.A. Corporate Responsibility, Accounting and Accountants. In Professionals' Perspectives of Corporate Social Responsibility; Idowu S.O., Filho W.L. Eds.; Springer, 2010, pp. 11-32.

V. Fernández Chulián, M. Constructing new accountants: the role of sustainability education. Rev. Cont. 2011, 14, 241-265.

VI. Idowu, S.O. Accounting for decision makers in a sustainable environment. In Theory and practice of corporate social responsibility; Idowu S.O., Louche C. Eds.; Springer, 2011, pp. 208-228.

VII. Fraser, M. "Fleshing out" an engagement with a social accounting technology. Account. Audit. Account. J. 2012, $25,508-534$.

VIII. Burritt, R.L.; Tingey-Holyoak, J. Forging cleaner production: the importance of academic-practitioner links for successful sustainability embedded carbon accounting. J. Clean. Prod. 2012, 36, 39-47.

IX. Ballou, B.; Casey, R.J.; Grenier, J.H.; Heitger, D.L. Exploring the Strategic Integration of Sustainability Initiatives: Opportunities for Accounting Research. Account. Horizons. 2012, 26, 265-288.

X. Schaltegger, S.; Zvezdov, D. In Control of Sustainability Information: Untangling the Role of Accountants. In Accounting and control for sustainability, Studies in Managerial and Financial Accounting; Songini, L.; Pistoni, A.; Herzig, C. Eds.; Emerald, 2013, pp. 265-296.

XI. Botes, V.; Low, M.; Chapman, J. Is accounting education sufficiently sustainable? Sustain. Account. Manag. Policy J. 2014, 5(1), 95-124.

XII. Çalışkan, A.Ö. How accounting and accountants may contribute in sustainability? Soc. Responsib. J. 2014, 10(2), 246-267.

XIII. Mistry, V.; Sharma, U.; Low, M. Management accountants' perception of their role in accounting for sustainable development. An exploratory study. Pac. Account. Rev. 2014, 26, 112-133.

XIV. Schaltegger, S.; Zvezdov, D. Gatekeepers of sustainability information: exploring the roles of accountants. J. Account. Organ. Change 2015, 11, 333-361.

XV. Seay, S. Sustainability is Applied Ethics. J. Legal Ethic. Regulatory Iss. 2015, 18, 63-70.

XVI. Williams, B.R. The local government accountants' perspective on sustainability. Sustain. Account. Manag. Policy J. 2015, 6, 267-287.

XVII. Schaltegger, S. Sustainability as a fundamental challenge for management accountants. In The role of management accountants, Local Variations and Global Influences; Goretzki L., Strauss E. Eds.; Routledge, 2017, pp. $274-291$.

XVIII. Boulianne, E.; Keddie, L.S.; Postaire, M. (Non) coverage of sustainability within the French professional accounting education program. Sustain. Account. Manag. Policy J. 2018, 9, 313-335.

XIX. Egan, M.; Tweedie, D. A "green" accountant is difficult to find. Can accountants contribute to sustainability management initiatives? Account. Audit. Account. J. 2018, 31, 1749-1773.

XX. Hoang, T. The Role of the Integrated Reporting in Raising Awareness of Environmental, Social and Corporate Governance (ESG) Performance. Stakeholders Gov. Responsib. 2018, 14, 47-69.

XXI. Tingey-Holyoak, J.; Pisaniello, J.D. Water accounting knowledge pathways. Pac. Account. Rev. 2019, 31, 258-274.

XXII. Margerison, J.; Fan, M.; Birkin, F. The prospects for environmental accounting and accountability in China. Account. Forum 2019, 43, 327-347.

XXIII. Oyewo, B.M. Outcomes of interaction between organizational characteristics and management accounting practice on corporate sustainability: the global management accounting principles (GMAP) approach. J. Sustain. Fin. Invest. 2020. doi:10.1080/20430795.2020.1738141. 


\section{References}

1. Crutzen, N.; Herzig, C. A review of the empirical research in management control, strategy and sustainability. Perform. Meas. Manag. Control. Glob. Issues 2013, 26, 165-195. [CrossRef]

2. De Villiers, C.J.; Rouse, P.; Kerr, J. A new conceptual model of influences driving sustainability based on case evidence of the integration of corporate sustainability management control and reporting. J. Clean. Prod. 2016, 136, 78-85. [CrossRef]

3. Henri, J.-F.; Journeault, M. Eco-control: The influence of management control systems on environmental and economic performance. Account. Organ. Soc. 2010, 35, 63-80. [CrossRef]

4. Lueg, R.; Radlach, R. Managing sustainable development with management control systems: A literature review. Eur. Manag. J. 2016, 34, 158-171. [CrossRef]

5. Schaltegger, S. Sustainability as driver of corporate success. Control. Z. 2010, 22, 238-243. [CrossRef]

6. Schaltegger, S.; Sturm, A. Eco-Efficiency through Eco-Control; VDF: Zurich, Switzerland, 1995.

7. Burritt, R.L.; Schaltegger, S. Sustainability accounting and reporting: Fad or trend? Account. Audit. Account. J. 2010, 23, 829-846. [CrossRef]

8. Chiucchi, M.S. Intellectual capital accounting in action: Enhancing learning through interventionist research. J. Intellect. Cap. 2013, 14, 48-68. [CrossRef]

9. Emsley, D. Restructuring the management accounting function: A note on the effect of role involvement on innovativeness. Manag. Account. Res. 2005, 16, 157-177. [CrossRef]

10. Ma, Y.; Tayles, M. On the emergence of strategic management accounting: An institutional perspective. Account. Bus. Res. 2009, 39, 473-495. [CrossRef]

11. Goretzki, L.; Strauss, E.; Weber, J. An institutional perspective on the changes in management accountants' professional role. Manag. Account. Res. 2013, 24, 41-63. [CrossRef]

12. Hyvönen, T.; Järvinen, J.; Pellinen, J. Dynamics of creating a new role for business controllers. Nord. J. Bus. 2015, 64, 21-39.

13. Vaivio, J. Mobilizing local knowledge with 'Provocative' non-financial measures. Eur. Account. Rev. 2004, 13, 39-71. [CrossRef]

14. Chiucchi, M.S. Measuring and reporting intellectual capital. Lessons learnt from some interventionist research projects. J. Intellect. Cap. 2013, 14, 395-413. [CrossRef]

15. Giuliani, M.; Marasca, S. Construction and valuation of intellectual capital: A case study. J. Intellect. Cap. 2011, 12, 377-391. [CrossRef]

16. Giuliani, M.; Chiucchi, M.S. Guess who's coming to dinner: The case of IC reporting in Italy. J. Manag. Gov. 2018, 23, 403-433. [CrossRef]

17. Mio, C.; Marco, F.; Pauluzzo, R. Internal application of IR principles: Generali's Internal Integrated Reporting. J. Clean. Prod. 2016, 139, 204-218. [CrossRef]

18. CIMA. Sustainability and the role of the management accountant. Res. Exec. Summ. Ser. 2011, 7, 1-14.

19. Massaro, M.; Dumay, J.; Guthrie, J. On the shoulders of giants: Undertaking a structured literature review in accounting. Account. Audit. Acc. J. 2016, 29, 767-801. [CrossRef]

20. Denyer, D.; Tranfield, D. Using qualitative research synthesis to build an actionable knowledge base. Manag. Decis. 2006, 44, 213-227. [CrossRef]

21. Petticrew, M.; Roberts, H. Systematic Reviews in the Social Sciences: A Practical Guide; John Wiley \& Sons: Hoboken, NJ, USA, 2008.

22. Tranfield, D.; Denyer, D.; Smart, P. Towards a Methodology for Developing Evidence-Informed Management Knowledge by Means of Systematic Review. Br. J. Manag. 2003, 14, 207-222. [CrossRef]

23. Alvesson, M.; Deetz, S. Doing Critical Management Research; Sage: London, UK, 2000.

24. Secundo, G.; Ndou, V.; Del Vecchio, P.; De Pascale, G. Knowledge management in entrepreneurial universities: A structured literature review and avenue for future research agenda. Manag. Decis. 2019, 57, 3226-3257. [CrossRef]

25. Massaro, M.; Dumay, J.; Garlatti, A. Public sector knowledge management: A structured literature review. J. Knowl. Manag. 2015, 19, 530-558. [CrossRef]

26. Traxler, A.A.; Schrack, D.; Greiling, D. Sustainability reporting and management control—A systematic exploratory literature review. J. Clean. Prod. 2020, 276, 122725. [CrossRef]

27. Ahrens, T.; Chapman, C.S. Occupational identity of MAs in Britain and Germany. Eur. Account. Rev. 2020, 9, 477-498. [CrossRef]

28. Harzing, A.-W. A preliminary test of Google Scholar as a source for citation data: A longitudinal study of Nobel prize winners. Science 2013, 94, 1057-1075. [CrossRef]

29. Harzing, A.-W. A longitudinal study of Google Scholar coverage between 2012 and 2013. Science 2014, 98, 565-575. [CrossRef]

30. Dumay, J.; Bernardi, C.; Guthrie, J.; DeMartini, P. Integrated reporting: A structured literature review. Acc. Forum 2016, 40, 166-185. [CrossRef]

31. Cuozzo, B.; Dumay, J.; Palmaccio, M.; Lombardi, R. Intellectual capital disclosure: A structured literature review. J. Intellect. Cap. 2017, 18, 9-28. [CrossRef]

32. Jones, M.J. Accounting for the environment: Towards a theoretical perspective for environmental accounting and reporting. Account. Forum 2010, 34, 123-138. [CrossRef] 
33. Ballou, B.; Casey, R.J.; Grenier, J.H.; Heitger, D.L. Exploring the Strategic Integration of Sustainability Initiatives: Opportunities for Accounting Research. Account. Horiz. 2012, 26, 265-288. [CrossRef]

34. Tilt, C.A. Corporate Responsibility, Accounting and Accountants. In Professionals' Perspectives of Corporate Social Responsibility; Idowu, S.O., Filho, W.L., Eds.; Springer: Berlin/Heidelberg, Germany, 2010; pp. 11-32.

35. Fraser, M. "Fleshing out" an engagement with a social accounting technology. Account. Audit. Account. J. 2012, 25, 508-534. [CrossRef]

36. Çalişkan, A.Ö. How accounting and accountants may contribute in sustainability? Soc. Responsib. J. 2014, 10, 246-267. [CrossRef]

37. Guthrie, J.; Ricceri, F.; Dumay, J. Reflections and projections: A decade of Intellectual Capital Accounting Research. Br. Account. Rev. 2012, 44, 68-82. [CrossRef]

38. Elkington, J. Cannibals with Forks: The Triple Bottom Line of 21st Century Business; Capstone: Oxford, UK, 1997.

39. Elkington, J. Partnerships from cannibals with forks: The triple bottom line of 21st-century business. Environ. Qual. Manag. 1998, 8, 37-51. [CrossRef]

40. Järvinen, J. Shifting NPM agendas and MAs' occupational identities. Account. Audit. Account. J. 2009, 22, 1187-1210. [CrossRef]

41. Friedman, A.L.; Lyne, S.R. The beancounter stereotype: Towards a general model of stereotype generation. Crit. Perspect. Account. 2001, 12, 423-451. [CrossRef]

42. Järvenpää, M. Making Business Partners: A Case Study on how Management Accounting Culture was Changed. Eur. Account. Rev. 2007, 16, 99-142. [CrossRef]

43. Krippendorff, K. Content Analysis: An Introduction to Its Methodology; Sage Publications: Los Angeles, CA, USA, 2018.

44. R Core Team. R: A Language and Environment for Statistical Computing; R Foundation for Statistical Computing: Vienna, Austria, 2018; Available online: https:/ / www.R-project.org (accessed on 20 December 2020).

45. Gamer, M.; Lemon, J.; Fellows, I.; Singh, P. Coefficients of Interrater Reliability and Agreement for Quantitative, Ordinal and Nominal Data. 2012. Available online: https://cran.r-project.org/web/packages/irr/index.html (accessed on 20 December 2020).

46. Lewis, T. Debate: Public Sector Sustainability Reporting-Implications for Accountants. Public Money Manag. 2008, 28, 329-331. [CrossRef]

47. Botes, V.; Low, M.; Chapman, J. Is accounting education sufficiently sustainable? Sustain. Account. Manag. Policy J. 2014, 5, 95-124. [CrossRef]

48. Mistry, V.; Sharma, U.; Low, M. Management accountants' perception of their role in accounting for sustainable development. Pac. Account. Rev. 2014, 26, 112-133. [CrossRef]

49. Williams, B. The local government accountants' perspective on sustainability. Sustain. Account. Manag. Policy J. 2015, 6, 267-287. [CrossRef]

50. Boulianne, E.; Keddie, L.S.; Postaire, M. (Non) coverage of sustainability within the French professional accounting education program. Sustain. Account. Manag. Policy J. 2018, 9, 313-335. [CrossRef]

51. Schaltegger, S.; Zvezdov, D. Gatekeepers of sustainability information: Exploring the roles of accountants. J. Account. Organ. Chang. 2015, 11, 333-361. [CrossRef]

52. Burritt, R.L.; Tingey-Holyoak, J. Forging cleaner production: The importance of academic-practitioner links for successful sustainability embedded carbon accounting. J. Clean. Prod. 2012, 36, 39-47. [CrossRef]

53. Tingey-Holyoak, J.; Pisaniello, J.D. Water accounting knowledge pathways. Pac. Account. Rev. 2019, 31, 258-274. [CrossRef]

54. Guthrie, J.; Petty, R. Intellectual capital: Australian annual reporting practices. J. Intellect. Cap. 2000, 1, 241-251. [CrossRef]

55. Adams, S.; Simnett, R. Integrated Reporting: An Opportunity for Australia's Not-for-Profit Sector. Aust. Account. Rev. 2011, 21, 292-301. [CrossRef]

56. Dumay, J.; Hossain, M.D.A. Sustainability Risk Disclosure Practices of Listed Companies in Australia. Aust. Account. Rev. 2019, 29, 343-359. [CrossRef]

57. Higgins, C.; Stubbs, W.; Tweedie, D.; McCallum, G. Journey or toolbox? Integrated reporting and processes of organisational change. Account. Audit. Account. J. 2019, 32, 1662-1689. [CrossRef]

58. Stubbs, W.; Higgins, C. Integrated Reporting and internal mechanisms of change. Account. Audit. Account. J. 2014, 27, 1068-1089. [CrossRef]

59. Hoang, T. The Role of the Integrated Reporting in Raising Awareness of Environmental, Social and Corporate Governance (ESG) Performance. Dev. Corp. Gov. Responsib. 2018, 14, 47-69. [CrossRef]

60. Idowu, S.O. Accounting for decision makers in a sustainable environment. In Theory and Practice of Corporate Social Responsibility; Idowu, S.O., Louche, C., Eds.; Springer-Verlag: Berlin/Heidelberg, Germany, 2011; pp. 208-228.

61. Seay, S. Sustainability is Applied Ethics. J. Legal Ethic. Regul. Iss. 2015, 18, 63-70.

62. Lodhia, S.K. The accounting implications of the sustainable development bill. Soc. Environ. Account. J. 2001, 21, 8-11. [CrossRef]

63. Fernández Chulián, M. Constructing new accountants: The role of sustainability education. Rev. Cont. 2011, 14, 241-265. [CrossRef]

64. Egan, M.; Tweedie, D. A "green" accountant is difficult to find. Can accountants contribute to sustainability management initiatives? Account. Audit. Account. J. 2018, 31, 1749-1773. [CrossRef] 
65. Schaltegger, S.; Zvezdov, D. In Control of Sustainability Information: Untangling the Role of Accountants. In Accounting and Control for Sustainability, Studies in Managerial and Financial Accounting; Songini, L., Pistoni, A., Herzig, C., Eds.; Emerald: Bingley, UK, 2013; pp. 265-296.

66. Oyewo, B.M. Outcomes of interaction between organizational characteristics and management accounting practice on corporate sustainability: The global management accounting principles (GMAP) approach. J. Sustain. Financ. Investig. 2020, 1-35. [CrossRef]

67. Margerison, J.; Fan, M.; Birkin, F. The prospects for environmental accounting and accountability in China. Account. Forum 2019, 43, 327-347. [CrossRef]

68. Brundtland, G. Our common future: The World Commission on Environment and Development; Oxford University Press: Oxford, UK, 1987.

69. Schaltegger, S. Sustainability as a fundamental challenge for management accountants. In The Role of Management Accountants, Local Variations and Global Influences; Goretzki, L., Strauss, E., Eds.; Routledge: London, UK; New York, NY, USA, 2017; pp. 274-291.

70. Caglio, A. Enterprise Resource Planning systems and accountants: Towards hybridization? Eur. Account. Rev. 2003, 12, 123-153. [CrossRef]

71. Lantto, A.-M. Business Involvement in Accounting: A Case Study of International Financial Reporting Standards Adoption and the Work of Accountants. Eur. Account. Rev. 2014, 23, 335-356. [CrossRef]

72. Burns, J.; Vaivio, J. Management accounting change. Manag. Account. Res. 2001, 12, 389-402. [CrossRef]

73. Scapens, R.W.; Jazayeri, M. ERP systems and management accounting change: Opportunities or impacts? A research note. Eur. Account. Rev. 2003, 12, 201-233. [CrossRef]

74. Lukka, K. Total accounting in action: Reflections on sten Jönsson's Accounting for Improvement. Account. Organ. Soc. 1998, 23, 333-342. [CrossRef] 